\title{
The Messages of Islamic Communication at One Roof System (SAMSAT) Sibolga, Indonesia
}

\author{
Hakim $^{1}$, Syukur Kholil ${ }^{2}$, Yusnadi ${ }^{2}$ \\ ${ }^{I}$ Ph.D Student in State Islamic University of North Sumatera (UINSU), Medan, Indonesia \\ ${ }^{2}$ Lecturer in State Islamic University of North Sumatera (UINSU), Medan, Indonesia \\ wildanansori22@gmail.com
}

\begin{abstract}
This research deals with the messages of Islamic communication at one roof system (Samsat) Sibolga, Indonesia. This research is conducted by using qualitative approach. The result shows that Samsat city uses communication patterns and other forms of communication which are divided into four forms, there are: Intra-personal communication (communicating with oneself), Inter-personal communication (communicating privately between one person and one person), group communication and organizational communication. These communication is carried out by all parties related to the records must be carried out outside of working hours. Services provided at one roof system (Samsat) Sibolga city are carried out by all Samsat officer starting from parking staff to service officer with the aim of effective Samsat services in Sibolga city. Communication messages which are conveyed by Samsat Sibolga City are divided into three things, there are: true and firm words and good (Qaulan Sadida), Fragile words, (Qaulan Balighah), and easy-to-understand words (Qaulan Layina). In addition, communication messages to be conveyed by Samsat Sibolga City also have other aims, there are: 1. Comply with the state administration including administration of compliant vehicles 2. Inviting actively and on target, as well as good management institutionally.
\end{abstract}

Keywords : Messages; Islamic Communication; One Roof System (Samsat) Sibolga

\section{Introduction}

In a state organization or institution such as the office of samsat, two-way communication is needed in a balanced and communicative manner. This is where human relations are needed as well as communicators in the office with community communicants. In principle, humans are always obedient, happy to be informed and explained, does not like to criticize and need a leader in this case are the communicators of Samsat officers. In the theory of human relations as noted by Syukur Khalil from Abdus Syukur (1991), there are at least four relationships that are noteworthy to be closer to seeing the extent of the effectiveness of motorized vehicle tax services at the Regional Tax and Retribution Management Agency of North Sumatra Province Cq. UPT Samsat, Sibolga City, North Sumatra Province. First, institutions or organizations move with the aim of meeting human needs. Secondly, institutions and humans are interdependent, thirdly, institutions and humans need each other to live and fourthly if the relationship between the leader of Samasat and the community is harmonious, then both of them will benefit greatly, where employees try their best to improve performance in terms of tax revenues and vehicle retribution.

In collecting the tax of motor vehicle at the Samsat Office in Sibolga city is needed for an effective and efficient service where the recipient of the order has characteristics such as heterogeneity in the composition of its members from various groups of society. Contains individuals who do not know each other and are separate from one another (do not gather) and do not interact with each other too. In addition, there is no formal leader or organization. In this kind of character, the servant or communicator truly understands the communicant character so that the service can run well, especially communication in Islamic communication reviews. As a service that involves many people, the effectiveness of service communication 
at the Joint Office of Samsat in Sibolga City seeks to create quality communication services. Because quality service will have a clear impact on the receipt of motor vehicle tax revenues. Realization of motor vehicle tax will certainly affect the amount of Regional Original Income (PAD) in each year in the Sibolga City Samsat office.

As is known that the motor vehicle tax is one of the potential sources of Regional Original Income (PAD). In this case, the regional government, that is the Regional Revenue Service (DISPENDA), is very interested in paying attention to the growth in the number of motorized vehicles that are increasing rapidly in each region. In line with this, the government sees a great opportunity to make all motor vehicles owned by taxpayers to become objects of motor vehicle taxation, this is related to the development and expansion of budgetary functions that require local governments to continuously explore the resources they have and considered potential in generating income for the region.

The motor vehicle tax is levied on the ownership and / or mastery of motorized vehicles as well as being the object of tax, and the tax subject is an individual or body as the owner of a motorized vehicle. In this case the writer compares the tax revenue of motorized vehicles and turns the name of Tapanuli Tengah District with the Sibolga City. In accordance with the list of realization of acceptance of PKB / BBN-KB 5 (Five) last year (T.A. 2013 s / d 2017) data are obtained from UPT. PUSINFO Dispendasu at Sisingamangaraja street Km 5.5 Medan.

Table 1. Data for the last 5 (five) years (T.A.2013 until 2017)

\begin{tabular}{|l|l|l|l|l|l|l|l|}
\hline \multirow{2}{*}{$\begin{array}{l}\text { Name } \\
\text { of UPT }\end{array}$} & \multirow{3}{*}{ T. A } & \multicolumn{4}{|c|}{ PKB } & \multicolumn{3}{c|}{ BBN-KB } \\
\cline { 3 - 8 } & & Target & Realization & Percentage & Target & Realization & Percentage \\
\hline Sibolga & 2013 & 13.017 .653 .725 & 12.395 .516 .120 & 95,22 & 27.016 .465 .027 & 18.629 .061 .088 & 68,95 \\
\cline { 2 - 8 } & 2014 & 13.665 .521 .060 & 13.556 .328 .047 & 99,20 & 19.813 .930 .383 & 17.467 .258 .501 & 88.16 \\
\cline { 2 - 8 } & 2015 & 11.288 .878 .600 & 11.305 .138 .539 & 100,14 & 13.253 .803 .257 & 12.153 .803 .257 & 91.70 \\
\cline { 2 - 8 } & 2016 & 10.457 .512 .223 & 11.412 .237 .957 & 109,13 & 11.588 .722 .495 & 11.749 .718 .745 & 101,39 \\
\cline { 2 - 8 } & 2017 & 10.477 .083 .915 & 11.803 .948 .931 & 112,66 & 9.281 .606 .128 & 10.125 .370 .864 & 109,09 \\
\hline
\end{tabular}

From the table above shows that not achieving the target is charged to the UPT Samsat Sibolga, while the UPT Samsat neighbor who also performs Motor Vehicle Tax services turns out almost every year can be achieved, this may occur if not the primary services are carried out for example in intrapersonal communication, interpersonal, public and mass becomes a phenomenon in service especially in motorized vehicle tax services. As we know that the tax target is a need for dharuriyah (urgent) that concerns the public interest that must be achieved. It may be a communication error either from the aspect of the methodology or from the communication function experiencing obstacles and very serious constraints. If in reality (Das sein) that should be in the table that should be achieved but vice versa (Das sollen) in reality is not fulfilled. Here it needs to be seen dialectically whether the communion of services provided is not in accordance with what was initiated by Islam with the communication that it built was divine and human at once.

Information delivery activities occur at the Samsat Office in the Motor Vehicle Tax Service in Sibolga City. The use of service information symbols is usually in the form of directing taxpayers in the form of images directing the fast process and easy to pay vehicle tax in offices with Samsat in the Motor Vehicle Tax Service of Sibolga City. Even the graphs and payment steps were also submitted in the form of brokers and leaflets for vehicle taxpayers. 
Therefore, usually this information delivery activity can be called effective service or commonly called service effectiveness.

\section{Review of Literatures}

\subsection{Communication Effectiveness}

Communication is the process of exchanging messages and making meaning. People know that they will be able to capture the meaning of a message that is exactly the same. So effective communication depends on our ability to understand the meaning of the message during the interaction process (message exchange). In other words, effective communication can reduce understanding of the meaning of messages received or delivered. Even though we cannot capture the meaning of a message that is truly the same as someone else's, it does not mean that effective communication cannot be done, it's just difficult or imperfect.

When communicating, we capture the meaning (interpret) the message that we make and give to others. We are usually not aware of this but actually we often do it. Two people who communicate can be said to communicate effectively if they can interpret the message sent and received even though the meaning is not entirely the same. Powers and Lowrey (1984) say that effective communication can occur if there is a match between 2 or more people when communicating. Triandis (1977) states that effective communication consists of making meaning that is isomorphic (isomorphic means being the same, understanding nature through statements of quality and characteristics of something).

Ineffective communication with strangers can occur for several reasons. Maybe because it doesn't convey the message well to others. Foreigners also misunderstand the message we convey. Second, this can occur alternately. These problems can occur due to the way the pronunciation of words that are not (pronunciation), wrong sentence structure (grammar), do not understand the topic of conversation, do not know each other, do not understand the language of others not fluent in using other people's languages. And also caused by social factors. If we know each other or are fluent in using other people's languages, we will find it easier to get to know each other both the behavior and the meaning of the language used in communication.

\subsection{Communication}

The communication process is essentially a part of human activity in social relations. This activity shows that humans have an instinct to live with others. It is this association that encourages people to make relations with each other, both for individuals and for other groups. This relationship between individuals is called social interaction. In other words, a relationship process that influences each other influences. So social interaction (social interaction) is a relationship that occurs dynamically among fellow humans. Soekanto stated, that social interaction is the main requirement for the occurrence of social activities. The intended interaction is the interaction between individuals and individuals, interactions between individuals and groups, and interactions between groups and groups.

In that interaction communication occurs and the process of conveying thoughts or feelings by someone (communicator) to others (communicants). Thoughts can be ideas, information, opinions and others that arise from his mind. Feelings can be beliefs, certainty, doubts, worries, anger, courage, excitement and so on that arise from the bottom of the heart. 
Mark L. Knapp, as quoted by Jalaluddin Rachmat, mentions five types of non-verbal communication functions, namely:

a. Repetition; repeat ideas that have been verbally explained.

b. Substitution; replacing verbal symbols.

c. Contracts; reject verbal messages or give other meanings to verbal messages.

d. Complement; complement and enrich the meaning of nonverbal messages.

Accentuation; confirm the verbal message or underline it. ${ }^{1}$ Second, the secondary communication process is the process of communicating the message by a communicator to others by using a tool or facility as the second medium in launching communication. Communicators use this second media because the communicant who is the target of his communication is far away or many in number or both, far and many. If the communicant is far away, a letter or telephone is used; if you use a lot of loudspeakers; when far and far, newspapers, radio or television are used.

Like the definition of communication, the classification of types or forms of communication among experts is also different from each other. The classification is based on the viewpoint of each expert according to his experience and field of study. For example, a group of American communication scholars who wrote the book Human Communication (1980) divided communication into five types or types, namely Interpersonal Communication (Small Interpersonal Communication), Small Group Communication, Organizational Communication, Mass Communication (Mass Communication) and Public Communication (Public Communication).

Joseph A. Devito, a professor of communication at City University of New York in his book Communicology (1982) divides communication into four types, namely Interpersonal Communication, Small Group Communication, Public Communication and Mass Communication.

According to communication science experts classify the distribution of communication in various forms. As explained by Dedy Mulyana in his book entitled An Introduction to Communication Science that communication seen from the communication participants is divided into several parts, namely: Communication with Self, Interpersonal Communication, Mass Communication, Organizational Communication, and Group Communication.

\subsection{Motor Vehicle Tax Services and Name Transfer Fee}

In an Indonesian dictionary in Mukarom the term service comes from the word "layan" which means helping to prepare or take care of what others need for acts of service. The word service is interpreted as a matter of how to serve, service services, and facilities provided in connection with the sale and purchase of goods / services.

In principle, there are many types of services provided by the government, especially those that are placed in the context of public policies which can be in the form of reglative versus deregulative or redtrictive versus nonrestrictive, and allocative versus distributive / redistributive. However, generically the services provided to the government are divided into three, namely: (1) Primary services; (2) Secondary services; (3) Tertiary services.

Boediono stated that service is a process of assistance to others in certain ways that require sensitivity and interpersonal relationships in order to create satisfaction and success.

\footnotetext{
${ }^{1}$ Jalaluddin Rakhmad, Psikologi Komunikasi (Bandung: Remaja Rosdakarya, 2000), P. 287.
} 
While according to Gie defines service is an activity in an organization or agency that is carried out to practice and devote themselves to the community.

Based on the above definition, it can be concluded that service is an activity carried out by an organization or institution that is aimed at the interests of the community which can take the form of money, goods, ideas or letters based on sincerity, pleasure, honesty, prioritizing satisfaction for those who receive service.

According to Kurniawan in Sinambela, public service is defined as the service provider (serving) the needs of people or communities who have an interest in the organization in accordance with the basic rules and established procedures.

While public services according to the Decree of the Minister of State for Administrative Reform (Men-PAN) Number 81 of 1993 are all forms of public service activities carried out by central government agencies, in the regions, and the environment of State / Regional Enterprises in the form of goods and services, both in the framework of efforts to fulfill the needs of the community and in the context of efforts to meet the needs of the community and in the framework of implementing the provisions of legislation.

From the above definition it can be understood that public service is a type of business that is managed by the government in the form of goods and services to serve the interests of the community without being oriented.

The purpose of public service is basically to satisfy the community. To achieve satisfaction, quality service is demanded as reflected in:

1. Transparency, namely services that are open, easy and accessible to all parties who need and are provided adequately and easily understood.

2. Accountability, that is, services that can be accounted for in accordance with the provisions of the legislation.

3. Conditional, namely service that is in accordance with the conditions and the ability of the giver and recipient of the service by sticking to the principles and efficiency and effectiveness.

4. Participatory, namely services that can encourage the participation of the community in the implementation of public services by paying attention to the aspirations, needs, and expectations of the community.

5. Equality of rights, namely services that do not discriminate are seen from any aspect, especially ethnicity, race, religion, class, social status and others.

6. Balance of rights and obligations, namely services that consider aspects of justice between providers and recipients of services.

With the existence of clear and open service procedures, the community in the management of interests can easily find out the procedures or procedures for services that must be passed. So that the service itself will satisfy the community. The target of public services is actually satisfaction, which consists of two major components, namely services and products.

\subsection{Communication and Public Service in the Islamic Perspective}

Communication in Arabic is known as al-ittisal which originates from the root of the wasola which means 'convey' as found in the Qur'an Suroh al-Qasas verse 51:

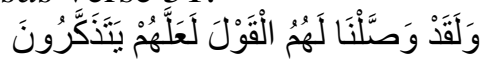

Meaning: "And indeed We have delivered Our words (Al-Qur'an) to them so that they get a lesson". (Q.S. al-Qasas: 51) 
Then Mahyuddin Abd. Halim quoted by Syukur Kholil wrote that Islamic communication is the process of delivering or passing on the essence of the truth of Islam to the public which is carried out continuously by referring to the Qur'an and al-Sunnah either directly or indirectly, through general or special media intermediaries which aims to form a true general view based on the nature of religious truths and give an impression on one's life in aspects of aqeedah, worship and muamalah.

Thus, in the theoretical and practical aspects, Islamic communication can be different from communication according to the general communication perspective, because Islamic communication is based on the Qur'an and Hadith that uphold the truth, when general communication prioritizes political and material benefits.

The essence (essence) of Islamic communication is to invite people to the path of da'wah which emphasizes religious and socio-cultural values, namely by using the principles and principles contained in the Qur'an and Hadith. The principle is not just the delivery of messages and the occurrence of changes in communicant behavior, but the establishment of a network of social interactions that are normative and harmonious. This principle distinguishes the concept of communication from the Islamic perspective with communication in a Western perspective that seems more cultural bound and much more detached from normative elements.

In the perspective of Islamic communication, the process of delivering messages from communicators to communicants must be delivered honestly and in accordance with the principles contained in the values of the Qur'an and Sunnah, because such is considered a part of worship. The application of the principles of Islamic communication takes place between humans and their God. This is the main foundation of Islamic communication. Two things need to be considered as the most fundamental difference between the communication of the Islamic perspective and the communication of the Western perspective, namely: first, Western communication is individualistic and value-free and it turns out that reality cannot build a harmonious social system; second, Islamic communication is believed to have an application conception of how harmonious living systems and messages conveyed contain elements that direct humans to the benefit of the world and the hereafter. This value is one of the peculiarities of Islamic Communication studies, so that it becomes part of Islamic studies. In an Islamic perspective, the communication theory must be in accordance with culture and religion.

\section{Research Methods}

The type of the research is qualitative research. According to Strauss and Corbin, qualitative research is a type of research that produces findings that cannot be obtained by using statistical procedures or other ways of quantification. One reason researchers use a qualitative approach is that qualitative research can reveal phenomena that occur related to shapes, messages, symbols and constraints and solutions, so that they discover and understand what is hidden behind the phenomena that occur.

Location is the place where research will be conducted. This research was conducted at the samsat office in Sibolga City, North Sumatra Province. Seeing the condition of the period for three consecutive years one of samsat in North Sumatra Province, Sibolga City, did not reach the target of Regional Original Income of the sub-sector of motor vehicle tax. So the location of the samsat office in Sibolga City, North Sumatra Province will be the object of research study. The time of the study was conducted from February 2018 to February 2019. 
The research subjects were the leaders of the Dispenda Institution, National Police, PT. Jasa Raharja, Sibolga City, North Sumatra Province, including:

1. Kasat Lantas (Coordinator), AKP Septian Dwi Riyanto, SH., SIK (NRP. 86091931)

2. Kanit Reg Ident (Responsible Agency), IPTU Heriyanto Panjaitan (NRP. 72010027)

3. Baur Cheek Fisik, AIPTU R. Parhusip (NRP. 73040412)

4. Baur of Income, Bripda Emeli (NRP. 941259)

5. Baur of STNK, Bripda Uswatun Hasanah (NRP. 96080469)

6. Baur Asdok, Aipda Heru Siagian (NRP. 79020612)

7. Baur BPKB, Brigadier Heru Suriawan (NRP. 86041199)

8. Head of UPT Sibolga, Nazaruddin, S.Sos (Level I Trustee)

9. Ka. Subag TU, Hafri (Stylist)

10. Kasi Revenue and Determination, Zufrijal, S.Sos (Level I Stylist)

11. Head of Collection of Arrears Management, Ika Sartika, S.Sos (Level I Administrator)

12. Registration / SPT, Adi Badsha Pulungan

13. PT. Jasa Raharja, Widiako (Person in Charge)

As the object of research is an office with Samsat in motor vehicle tax services in Sibolga City, North Sumatra Province.

\section{Discussion}

The ultimate goal of Islam Communications is to make communication as an alternative communication, especially in upholding human values in accordance with the nature of human creation. The conformity of the values of communication with the dimensions of the creation of human nature gives benefits to human welfare.

Effectively, Islamic communication is the process of delivering or exchanging information using the principles and methods of communication in the Koran and hadith. Islamic communication can thus be defined as the process of delivering Islamic values from the communicator to the communicant by using the principles of communication in accordance with the Qur'an and Hadith.

Rules, principles, or ethics of Islamic communication are a guide of Muslims in communicating, both in intrapersonal, interpersonal communication in daily interactions, preaching verbally and in writing, and in other activities.

In various literature on Islamic communication we can find at least six types of speech or speech styles (qaulan) which are categorized as Islamic communication rules, principles, or ethics, there are (1) Qaulan Sadida, (2) Qaulan Baligha, (3) Qaulan Ma ' rufa, (4) Qaulan Karima, (5) Qaulan Layinan, and (6) Qaulan Maysura.

In assignment, the One Roof System, hereinafter referred to as SAMSAT, is a series of activities in the implementation of Motor Vehicle Registration and Identification (Ranmor), Motor Vehicle Tax Payment (PKB), Motor Vehicle Name Transfer Fee (BBNKB), and Traffic Accident Funds Donation payments and Road Transportation (SWDKLLAJ) in an integrated and coordinated manner at the samasat office. The purpose of the office with sasamsat is to provide motori vehicle registration and identification services (Ranmor), payment of taxes on 
motor vehicles, and donations of compulsory and coordinated traffic accident and road transport funds in a fast, accurate, transparent, accountable, and informative manner.

The samsat office is a forum for the National Police of the Republic of Indonesia in charge of traffic represented by the Dirlantas POLDA, the Regional Financial Management Work Unit that carries out provincial tax collection is represented by the Office of Revenue (Dispenda), and Business Entity in organizing samsat (PT Jasa Raharja). The three agencies above are referred to as the samsat Advisory Team which has its own service function in helping collect taxes and administering motorized vehicles.

In terms of communication, samsat is a forum for the government to serve the public in an orderly manner in the management of payment administration and motorized vehicle affairs. samsat functions as a communicator in conveying messages that have been regulated by the government and passed in a standard rule called the law.

At the beginning it was discussed how the form of communication carried out by samsat Sibolga city about the form of communication carried out in serving the community. The forms of communication are divided into three forms, namely intra-personal communication, interpersonal communication and group communication. Then the communication is carried out in accordance with Islamic rules as a form of service based on the Qur'an and Sunnah. So in this chapter, the messages of Islamic communication will be developed and carried out by samsat, Sibolga City.

In detail there are four messages to be conveyed by samsat Sibolga city in serving and making effective the community, there are:

1. Neat management in the organizational structure.

2. Active and wise invitation.

3. Beware and be careful of administrative matters.

4. Obey and obey the State administration which has been regulated by law.

The four messages of communication are channeled and in line with the principles of Islamic communication based on the Qur'an and Hadith. In detail the following is an explanation of communication messages carried out by samsat, Sibolga City.

\section{a. Organizational Management.}

Samsat Sibolga city is known to be intra-personal communication a form of communication in making samsat Services more effective ${ }^{2}$. The effective Service Perspective starts from oneself who intend to serve the people in the office where they work and are aware of the administration where they work.

Interview with the person in charge of PT. Jasa Raharja Widiako (December 2018).

"The eforts to effectively serve the public in administration are carried out massively by all parties to achieve service satisfaction felt by the community. The efforts were carried out by all parties starting from the highest ranks / superiors to subordinates by actively and massively coordinating so that all employees were directed to always be obedient in administration and rules to the appeal at samsat Sibolga City".

Obeying the obedience of administration that starts from the environment of its own work area makes samsat have management communication in building solidity for excellent service. The communication management was applied to the samsat Sibolga City environment in detail

\footnotetext{
${ }^{2}$ This communication was built by each employee in the SAMSAT office in Sibolga City.
} 
starting from employees who had the lowest position to the highest position in the samsat environment.

The management of communication in question is how people manage their communication processes with others in various communication contexts. For example in situations of interpersonal communication, group communication, and organizational communication.

\section{b. Actively and Targeted Inviting.}

The invitation sentence is a sentence as an extension of the meaning of the command sentence and is closely related to the second person. The invitation sentence is the sentence that states someone's invitation to the person they are talking to do something together. Invitational sentences are a form of sentence arrangement which is actually an extended command sentence and is closely related to the second person.

Active invitations can be carried out and carried out if the communication carried out by the communicator is done right on target. The message that provides effective service to the community through the invitation made must also make an impression on the communicant so that the effects produced are in accordance with the expectations desired by samsat as a communicator in inviting the public to obey the rules of administration of motorized vehicles.

In Islamic communication the solicitation of the invitation was Qaulant Baligha. The word baligh means precise, straightforward, eloquent, and clear meaning. Qaulan Baligha means using words that are effective, right on target, communicative, easily convoluted or long-winded.

Samsat Sibolga City tries to be active with the community. The invitation was carried out with the principle of Islamic communication which was active and communicative in nature so as to produce the right effect on the people in obeying the administration of motorized vehicles.

\section{c. Inviting Obedience to State Administration Affairs}

State Administration or public administration is a series of activities carried out by the state apparatus or the government to achieve state goals efficiently. In simple terms, the definition of public administration is the study of how to manage a public organization systematically.

Samsat is an administrative system that is in compliance with the rules of motorized vehicles as a form of state management as well as state revenue. Administration in the samsat region is regulated by the government through laws that are arranged neatly and systematically to facilitate the public in matters of motorized vehicles.

The purpose of state administration depends on the goals of the country itself and the objectives of a country in accordance with the philosophy of the country. The purpose of state administration in a democratic country is to achieve state goals that have been set by the people, namely to maintain security, carry out welfare, realize freedom and order and uphold justice than the people, or in other words to create a good life for the people.

Compliance with the administration of motorized vehicles through samsat has a function and purpose as a means of prosperity of the people in carrying out social welfare, as well as making the country capable to create a good life for the people. The form of social welfare is 
obtained from the funds of obedient citation of vehicle administration which is used as a tool to build state infrastructure. ${ }^{3}$

Obeying the administrative affairs of the State is an obligation and right for all Indonesian people in a democratic life. After being obedient to the administration, the State is obliged to provide good service to the people's interests or to serve the people's wishes. So that the administration of the state administration can be felt well.

Obeying the call to regulate this country in administrative management to obey the affairs of the State administration described by Allah SWT in Al-Quran Surah An-Nisa 58-59:

Meaning: Surely Allah tells you to deliver the message to those who have the right to receive it, and (tell you) if it establishes a law among men so that you determine justly. Surely Allah gives you the best teaching. Lo! Allah is ever Hearing, Seeing. O ye who believe, obey Allah and obey the Messenger (Him), and ulil amri among you then if you have different opinions about something, then return it to Allah (the Quran) and the Messenger (sunnah), if you truly believe in Allah and the day after. That is more important (for you) and better the result. (Q.S.4: 58-59)

Qaulan Layina can also mean meaningful speech (easy to understand) and understood by the communicant so that it causes understanding. Other meanings are words that are pleasant or contain joyful things.

Meaning: And if you turn away from them to obtain the mercy from their Lord that you

hope for, then say to them Qaulan Maysura (easy saying) "(Surat al-Isra: 28). God's Word:

Meaning: Hey people, fear your God who created you from alone, and from him Allah created his wife; and from both of them God breeds many men and women. And fear Allah who by (uses) His name you ask each other, and (maintain) friendship relations. Surely Allah always watches over and watches over you.

One example in samsat administration of speech that is full of understanding is when one community has difficulty in managing the administration of motorized vehicles or is experiencing problems, as an institution has an obligation to communicate with the communicant to solve the problem, helping him with a language that is attentive and understanding so he can ease the burden or give suggestions to overcome the problem.

Qaulan Layina can be decomposed as a meaningful form of speech that is easy, which is easy to digest, easy to understand, and understood by the communicant. Other meanings are words that are pleasant or contain joyful things. Easy speech can also be broken down as a gentle form, with a sound that is pleasant to hear, and full of hospitality, so that it can touch the heart. What is meant by Qaulan layina is satirical words, not with straightforward or straightforward words, especially rude.

\section{Conclusion}

Samsat city uses communication patterns and other forms of communication which are divided into four forms, there are: Intra-personal communication (communicating with oneself), Inter-personal communication (communicating privately between one person and one person), group communication, and organizational communication. These communication is carried out by all parties related to the records must be carried out outside of working hours.

\footnotetext{
${ }^{3}$ Interview with Kasatlantas AKP Septian Dwi Riyanto.
} 
Services provided at one roof system (Samsat) Sibolga city are carried out by all Samsat officer starting from parking staff to service officer with the aim of effective Samsat services in Sibolga city. Communication messages which are conveyed by Samsat Sibolga City are divided into three things, there are: true and firm words and good (Qaulan Sadida), Fragile words, (Qaulan Balighah), and easy-to-understand words (Qaulan Layina). In addition, communication messages to be conveyed by Samsat Sibolga City also have other aims, there are: 1 . Comply with the state administration including administration of compliant vehicles 2 . Inviting actively and on target, as well as good management institutionally.

\section{References}

Ali, Muhammad, Kamus Lengkap Bahasa Indonesia Modern, Jakarta: Pustaka Amani, 1999. Amali, Muhammad Naim, Diposting 25 ${ }^{\text {th }}$ January 2015.

Arifin, Anwar, Strategi Komunikasi: Sebuah Pengantar Ringkas, Bandung: Armico, 1984.

Ardianto, Elvinaro, at el, Komunikasi Massa Suatu Pengantar, Bandung: Simbiosa Rekatam Media, 2004.

Ar-Rahman, Muhammad Abdul Malik, Zakat 1001 Masalah dan solusinya, Jakarta: Lintas Pustaka, 2003.

Arni Muhammad, Komunikasi Organisasi. Jakarta: Bumi Aksara, 2005

Az Zuhaili, Wahbah, Al Fiqhul Islami wa Adillatuhu Juz. II. Darul Fikr. Damaskus. 1996.

Budyatna, Muhammad, Teori-teori Mengenai Komunikasi Antar-Pribadi, Jakarta: Prenadamedia Group, 2015.

Buku Profil Badan Pengelolaan Pajak dan Retribusi Daerah Provinsi Sumatera Utara (BPPRDSU) Tahun 2017.

Bungin, Burhan, Sosiologi Komunikasi. Teori, Paradigma, dan Diskursus Teknologi Komunikasi di Masyarakat, Jakarta: Kencana, 2006.

, Sosiologi Komunikasi, Teori Paradigma, dan Diskursus Teknologi Komunikasi di MasyarakatI, Cet. 3, Jakarta: Kencana, 2008

Boediono, B, Pelayanan Prima Perpajakan, Jakarta: PT, Rineka Cipta, 2003.

Cangara, Hafied, Pengantar Ilmu Komunikasi, Jakarta: PT. Raja Grafindo Persada, 2000

Curtis, Dan B Floyd, James J., Winsor, Jerry L., Komunikasi Bisnis dan Profesional, Bandung: PT Remaja Rosdakarya, 2005.

Devito, Joseph A, The Interpersonal Communication Book. Fith Edition, New York: Harper and Row Publishers, 1989 .

Komunikasi Antar Manusia, Jakarta, t.tp, 1997.

Departemen Agama RI, Al-Qur'an Dan Terjemahnya, Bandung: CV. Penerbit Jumanatul 'AliArt (J-Art), 2005.

Departeman Agam RI, Alquran dan Terjemahan, Jakarta : Gema Insani Perss, 2001.

Dillard, P. \& D.H. Solomon. Measuring the relevance of relational frames, dalam Muhammad Budyatna. 2015. Teori-teori Mengenai Komunikasi Antar-Pribadi. Jakarta: Prenadamedia.

Dwiyanto, Agus, Manajemen Pelayanan Publik: Peduli, Inklusif, dan Kolaboratif., Yogyakarta: Gajah Mada University Press, 2012.

Effendi, Onong Uchjana, Ilmu Komunikasi Teori dan Praktek, Bandung: Remaja Karya, 1985

Emery, at el, Introduction to Mass Communications, New York: Dadd Mead \& Company, 1970 
Fajar, Marhaeni, Ilmu Komunikasi:Teori dan Praktik, Jakarta: Universitas Mercu Buana, 2009. Gusfahmi, Pajak Menurut Syariah, Edisi Revisi, Jakarta: Rajawali Press, 2011.

Ghani, Zulkifli Abdul, Islam, Komunikasi dan Teknologi Maklumat: Eksistensi Ilmu Komunikasi Islam, Bandung: Citapustaka, 2008.

Gie, The Liang, Ensiklopedi Administrasi, Jakarta: Gunung Agung, 1993.

Hussain, et.al., Dua Puluh Lima Soal Jawab Mengenai Komunikasi Islam. Pengarah, Pusat Pengembangan dan Pendidikan Lanjutan, Universiti Pertanian Malaysia, Serdang Selangor, Darul Ehsan, 1990.

Huraerah, Abu and Purwanto, Dinamika Kelompok, Bandung: Refika Aditama, 2012.

Harjani Hefni, Komunikasi Islam, Jakarta Pranadamedia Group, 2015.

Joseph Prokopenko. Productivity Management : A Practical Handbook (geneva : ILO. 1987.

Kambey, D.C, Landasan Teori Administrasi/Manajemen: Sebuah Intisari, Manado:Yayasan Tri Ganesha Nusantara, 2010.

Keputusan Menteri Pendayagunaan Aparatur Negara No.63 Tahun 2003 tentang Pelayanan Publik.

Kurniawan, Panca dan Agus Purwanto, Pajak dan Retribusi Daerah di Indonesia, Malang: Bayumedia Publishing, 2004.

Kholil, Syukur, Komunikasi Islam, Cet 1, Bandung: Citapustaka Media, 2007.

Kriyantono, R. Teknik Praktis Riset Komunikasi. Jakarta: Kencana, 2010

Liliweri. Alo, Komunikasi Antarpribadi, Bandung: Citra Aditya Bakti, 1991.

Moekijat, Teori Komunikasi. Bandung: Mandar Maju, 1993.

Manan, Abdul, Teori dan Praktek Ekonomi Islam, Yogyakarta: PT. Dana Bhakti Yasa, 1997.

Masmuh, Abdul, Komunikasi Organisasi Dalam Perspektif Teori dan Praktek, Jakarta: UMM Press, 2010.

Muqodim, Perpajakan, Yogyakarta: Uii Press dan Ekonisia, 2000.

Moenir, H.A.S. Manajemen Pelayanan Umum di Indonesia, Jakarta: Bumi Aksara, 2002.

Nugroho, Riant, Public Policy, Jakarta: PT Gramedia, 2014.

Nurdin, Pengantar Komunikasi Massa, Jakarta : Rajawali Press, 2007.

Peraturan Presiden Nomor 5 Tahun 2015 Tentang Peraturan Mengenai Penyelenggaraan Sistem Administrasi Manunggal Satu Atap.

Peraturan Daerah Provinsi Sumatera Utara Nomor 1 Tahun 2011 tentang Pajak Daerah Provinsi Sumatera Utara.

Pulungan, J. Sayuti, Fiqih Siyasah, Jakarta: PT. Raja Grafindo Persada, 1994.

Pratikno, Globalisasi Komunikasi, Jakarta: Pustaka Sinar Harapan, 1987.

Qardhawi, Yusuf, Hukum Zakat: Studi Komparatif Mengenai Status \&Filsafat Zakat Berdasarkan Qur-an and Hadist, Jakarta: LiteraAntar Nusa, 2007.

Rakhmat, Jalaluddin, Teori-teori Komunikasi. Bandung: PT Remaja Rosdakarya, 1990

Robbins, Stephen P., Teori Organisasi Struktur, Desain dan Aplikasi, San Diego: Prentice-Hall International, Inc, 1994.

Rosmawaty, HP, Mengenal Ilmu Komunikasi, Padjajaran: Widya, 2010.

Richard M. Steers. Gerald R. Ungson and Richard T. Mowday, Managing Effective Organizations: An Introduction, Boston. Massachusetts: Kent Publishing Company, 1993.

Ratminto and Atik, Manajemen Pelayanan Organiasi Bisnis (Bandung, Lentera : 2005.

Sastroputro, Santoso, Komunikasi Internasional, Jakarta: Sarana Interaksi, antar bangsa, Alumni, 1982. 
Suprato, Pelayanan Publik, Jakarta, Cipta Pustaka Insani : 2006

Sedermayanti, Good Governance (Kepemerintahan yang Baik) Bagian Kedua: Membangun Sstem Manajemen Kinerja guna Meningkatkan Produktivitas Menuju Good Governance (Kepemerintahan yang Baik), Bandung: Mandar Majum, 2004.

Siahaan, S.M., Komunikasi Pemahaman dan Penerapannya, Jakarta: PT.BPK Gunung Mulia, 1991

Siahaan, Marihot P., Pajak Daerah dan Retribusi Daerah, Jakarta: PT Raja Grafindo Persada, 2006.

Siagian, Sondang P, Eksekuti yang Efektif, Jakarta: Gunung Agung, 2006.

Supratiknya, A, Tinjauan Komunikasi Antar Pribadi, Yogyakarta: Kanisius, 1995.

Soekanto, Soerjono, Sosiologi: Suatu Pengantar, Jakarta: PT Raja Grafindo, 2002.

Spradley, Teknik Analisis Data Model Spradley. 2010. [Tersedia Online] http:// banets.blogspot.com/2010/08/analisis model spradley.html, di akses April 2015.

Strauss, Anselm \& Juliet Corbin, Dasar-dasar Penelitian Kualitatif, Yogyakarta: Pustaka Pelajar, 2003.

Satibi, al-Muwafaqat fi Ushul Fiqh, Beirut : Dar al-Ma'rifah, tt,.

Sondang P Siagian. Filsafat Adminstrasi . Jakarta: Rineka Cipta, 1997

Syukur Khalil, Metodologi Penelitian Komunikasi, Bandung : Citapustaka, 2016.

Wiryanto,Teori Komunikasi Massa, Jakarta: PT. Gramedia Widia Sarana Indonesia, 2000

Wahyu Ilaihi, Komunikasi Dakwah, PT. Remaja Rosdakarya, Bandung, 2010, Cet. 1

Widodo, Manajemen Sebuah Organisasi (Jakarta, Media Insani Perss : 2003.

Yusuf Qardhawi, Hukum Zakat : Studi Komparatif Mengenai Status \& Filsafat Zakat berdasarkan Qur-an dan Hadist, Jakarta : Litera Antar Nusa, 2007

Zaenal, Mukarom and Muhibudin Wijaya Laksana, Membangun Kinerja Pelayanan Publik, Bandung: Pustaka Setia, 2016. 